Адам М. Софронијевић

Прегледни рад

Универзитетска библотека

UDK 027.7:06.051(497.11)

„Светозар Марковић”, Београд

005:027.7(497.11)

sofronijevic@unilib.rs

\title{
ПРОЈЕКТИ У УНИВЕРЗИТЕТСКОЈ БИБЛИОТЕЦИ У БЕОГРАДУ
}

Сажетак: Универзитетска библиотека у Београду успешно је реализовала већи број пројеката са међународним и националним финансирањем у периоду после 2000. године. Многи од ових пројеката поставили су основе за тренутно постојеће радне процесе који дефинишу неке од доминантних токова библиотечко-информационе делатности у Србији и региону. У раду се презентују неки од најважнијих резулата пројектног пословања Универзитетске библиотеке из Београда у претходном периоду и описују најважнији и најуспешније реализовани пројекти са међународним и националним финансирањем. Размотрени су разултати и управљање овим пројектима, а указује се на могућности даљег развоја билбиотечко-информационе делатности кроз успешну реализацију пројектних активности и комбиновање пројектнихи редовних радних активности као стратешко опредељење менаџмента библиотека.

Кључне речи: пројекти, пројектно управљање, међународни пројекти, национални пројекти, Универзитетска библиотека „Светозар Марковић”, Србија.

\section{Увод}

Библиотечко-информациона делатност се у последњим деценијама, као и готово све области пословања и занимања, убрзано и стално мења. Сложеност ових промена може се мерити само са њиховом брзином, и готово сваке године потребно је изнова дефинисати многе појмове, концепте, а следствено томе и њихову имплементацију у библиотечко-информационој пракси. Пројекти су широм света, у готово свим секторима пословања, 
у претходном периоду препознати као успешан начин да се остваре нове и комплексне активности. ${ }^{1}$ Тако је и у библиотекама, у којима се највећи део нових радних процеса и послова уводи путем пројеката. ${ }^{2}$

По стандарду ISO10006 пројекат је јединствен процес, који се састоји од скупа координираних и контролисаних активности, са датумом почетка и краја активности, које се предузимају да би се остварио циљ који је одређен специфичним захтевима, укључујући и временска и ресурсна ограничења. Три најважније димензије које дефниишу један пројекат су: време, трошкови и обим активности. Параметри ове три димензије су међусобно повезани и интерактивни. ${ }^{3}$ Сваки пројекат карактерише специфичан животни циклус. Нема универзалне дефиниције пројектних фаза, нити сви пројекти пролазе кроз исте фазе, али најшире би се могло дефинсати да се пројекат може састојати од следећих фаза: концептуализација, планирање, извођење и завршетак, где се свака фаза дефинише и где сваку фазу означава важан документ као што је извештај о изводљивости, план изведбе, план алокације ресурса или извештај о евалуацији пројекта. ${ }^{4}$

Пројект менаџмент је специфична област менаџмента која омогућава успешне функције менаџмента у пројектном окружењу. Обухвата три кључна елемента који је чине различитим од других облика манаџмента: пројектни менаџер, пројектни тим и пројект менаџмент систем. Пројект менаџмент систем се састоји од организационе структуре, сегмента за порецесуирање информација и доношење одлука и процедура које омогућавају интеграцију хоризонталних и вертикалних елемената пројектне организације. ${ }^{5}$ Добро заснован и уходан пројект менаџмент систем фокусиран је на интегративно планирање и контролу као функције менаџмента које се издвајају по важности у пројектном контексту.

Управљање пројектима у контексту креативних индустрија или шире културне делатности, институција културе и науке, подразумева специфичности у планирању и извођењу пројеката, посебно ако је у питању

Andrew Munns and Bassam Bjeirmi, "The role of project management in achieving project success", International journal of project management 14, 2 (1996): 81-87.

2 Mark Winston and Tara Hoffman, "Project management in libraries", Journal of Library Administration 42, 1 (2005): 51-61.

3 Harold Kerzner, "Project management best practices: Achieving global excellence" (New York: John Wiley \& Sons, 2018).

4 Jack, Meredith, Samuel Mantel and Scott Shafer, "Project management: a managerial approach" (New York: John Wiley \& Sons, 2017).

5 Stefano Tonchia, "Project Cost Management and Finance", in Industrial Project Management (Berlin: Springer, 2018), 153-170. 
мултипројектно управљање. Потреба да се организациона структура и организациона култура прилагоде успешној реализацији пројектних задатака и усклађивању редовних радних процеса с пројектним токовима, као и преношење новоусвојених знања, вештина и радних процедура из пројектног у редовне радне токове захтева посебно систематско развијање менаџмент функција планирања и котроле. ${ }^{6}$

\section{Историјат пројектног пословања у Универзитетској библиотеци у Београду}

Почетак пројектног пословања у Универзитетској библиотеци у Београду везује се за 2002. годину и имплементацију ТЕМПУС пројеката Европске уније, као и за националне пројекте које у првој деценији 21. века финансира Министарство културе Републике Србије. Дуализам пројектног финансирања, кроз фондове ЕУ и министарстава Владе Републике Србије, до данас карактерише пројектно пословање Библиотеке, где је карактеристична разлика у обиму пословних захвата по ове две линије пројектног финансирања. Пројекти ЕУ већег су опсега и омогућавају значајније иновације у пословању, док пројекти националног финансирања претежно обезбеђују мање пословне опсеге, и уз неколико изузетака, резултују значајним, али релативно мањим иновацијама у пословању. Показало се, међутим, да успешно пројектно управљање које у мултипројектном моделу пословања уклапа предности и карактеристике ове две врсте пројеката, омогућава готово оптималне резултате пословања, имајући у виду основне организационе капацитете и редовне радне процесе који се реализују у Библиотеци. До сада је у Библиотеци успешно реализовано више од 20 пројеката националног финансирања, 6 пројеката са ЕУ финансирањем, а у току је реализација 3 пројекта националног финансирања. Такође, важно је напоменути да је библиотека кроз форму пројектног партнерства с великим бројем установа културе из Републике Србије и региона остварила завидне пословне резултате успешном реализацијом више од 10 оваквих пројеката, а тренутно је у току реалиазција 6 пројеката у којима је Библиотека партнерска установа и у том статусу је носилац пројектних активности.

По резултатима као најважније издвајамо пројекте с ЕУ финансирањем и неколико пројеката с националним финансирањем већег опсега

6 Dejan Petrović, Vesna Milićević i Adam Sofronijević, “Application of Project Management in Creative Industry", European Project Management Journal 7, 2 (2017): 59-66. 
пројектних активности. Два ТЕМПУС пројекта су омогућила увођење система за аутоматизацију пословања библиотека COBISS у Србију и то: TEMPUS UMI_JEP 16059-2001 "Building cooperative academic library network in Serbia: universities in Belgrade, Nis and Kragujevac" 2002-2004 и Tempus JEP 2009-4930 "New Library Services at Western Balkan Universities" 2010-2012. Кроз CIP ICT-PSP пројекат Europeana Newspapers: A Gateway to European Newspapers први пут су у Србији у библиотечку праксу увдени XML стандарди METS и ALTO који омогућавају машинску читљивост обрађених дигитализованих материјала, као и пуну читљивост текстова уз истовремено задржавање визуелне форме страница и сегментацију елемената материјала на логичке целине. У оквиру CIP ICT-PSP пројекта Europeana Libraries први пут су у већем обиму у домаћој библиотечкој пракси примењени EDM шема метаподатака и методи и организација пословања примерена за послове масовне дигитализације штампаних материјала културног наслеђа из фондова библиотека. У оквиру Horizon 2020 пројекта READ - Recognition and Enrichment of Archival Documents уведена је у Србију, по први пут, револуционарна нова технолгоија заснована на машинском учењу, која омогућава масовну дигиталиазцију помоћу уређаја ScanTent и апликације DocScan, као и рашчитавање руком писаних материјала културног наслеђа из фондова библиотека, архива и музеја помоћу програма Transkribus. У случају имплементације технолошких основа програма Transkribus нарочито је успешно примењено мултирпојектно управљање пројектима ЕУ и националног финансирања, у оквиру кога су остварени и синергијски ефекти сарадње са више од 10 институција културе и науке у Србији и региону, како би се ефекти нове технологије најбрже и најефикасније пренели до што ширег круга корисника и ефективно из пројектног модела примене пренели у редовне радне процесе. Први, по обиму пројектних активности опсежнији, а тиме и значајнији пројекат националног финансирања у Универзитетској библиотеци у Београду реализован је 2014. године у сарадњи са десетинама других библиотека и установа културе из Србије. У оквиру пројекта Универзитетска библиотека „Светозар Марковић” за мрежу јавних и високошколских библиотека Србије: пренос знања, садржаја и програмаодржани су специјални догађаји у готово 30 градова Србије и знања, садржаји и програми развијани пре тога годинама у Универзитетској библитоеци учињени су корисним великом броју библиотекара и других запослених у установамакултуре и њиховим корисницима. Наредне, 2015. године реализована су два важна пројекта с националним финансирањем, Магична дигитална Србија и Израда целовитог електронског каталога Универзитетске библи- 
отеке „Светозар Марковић”. У оквиру ова два пројекта уведени су потпуно нови радни процеси на инфраструктурним основама које до тада нису постојале. Набављен је уређај Магична кутија и успостављен је дигитални лисни каталог са функцијама прегледања и претраге дигитализованог лисног каталога. Пројекти су пример добре сарадње с институцијама јавне управе у Србији, конкретно Министарством културе и партнерским институцијама из иностранства, конркетно Универзитетом у Инзбруку и компнијом CCS из Хамбурга. У периоду 2016-2018. године успешно су реализована три пројекта националног финансирања заснована на технологији доступној кроз ЕУ Horizon 2020 пројекат READ - Recognition and Enrichment of Archival Documents, чиме је показано да је могуће остварити успешну синергијску пројектну активност пројеката националног и ЕУ финансирања у дужем року и кроз модел мултипројектног управљања пројектним активностима. Кроз пројекте Рашчитавање старе српске ћирилице: прошлост и српско писмо у новом веку, Рашчитана стара српска ћирилица: оживљена руком писана прошлост и Рашчитаност старе српске ћирилице: историја и традиција надохват руке свих остварени су изузетно значајни технолошки помаци у библиотечко-информационој делатности у Републици Србији, пре свега увођењем коришћења програма Tpanskribus у редовне и пројектне радне активности и остваривање конвергентности токова дигитализације руком писаних и штампаних материјала културног наслеђа у претраживу дигиталнубиблиотеку засновану на METSALTO стандардима. ${ }^{7}$ Успешан вишегодишњи континуитет пројектних активности које су значајно унапредиле пословање у сегменту обраде и презентације архивске и библиотечке грађе Универзитетске библиотеке у Београду остварен је током 2015. и 2016. године успешном реализацијом пројеката Истраживање, заштита и промоција архивске грађе на ћириличном писму кроз преписку књижевника 19. и 20. века, из Архивске збирке Јоце Вујића и Дигитализацација и презентација културног и научног наслеђа Архивске збирке Јоце Вујића и објављивање породичне преписке кнеза Милоша Обреновића. ${ }^{8}$ Током 2018. године покренута су два нова тока мултипројектних активности која се настављају и пројекти-

7 Aleksandar Jerkov i Adam Sofronijevic, "University of Belgrade library, Transkribus user experience", paper presented at Transkribus User Conference 2017, 2-3 November, Technical University of Vienna, Vienna, available at: https://read.transkribus.eu/wp-content/ uploads/2017/07/Jerkov_Uni_Belgrade_library.pdf (accessed 13 December 2018).

8 Tatjana Brzulović-Stanisavljević, "Zaostavština Joce Vujića”, u Biblionet: zbornik radova sa konferencije Dani matičnih biblioteka Srbije 2016 (Beograd: Zajednica matičnih biblioteka Srbije, 2016), 165-176. 
ма који су током текуће 2019. године у реализацији. У питању је масовна дигитализација кроз национално финансирање штампаног културног наслеђа у складу с препорукама Националног оквира за дигитализацију периодичних издања у Републици Србији у којој учествује већи број институција културе, пре свега библиотека, и где се кроз пројекат Претраживо културно наслеђе Србије: богаћење дигиталне ризнице бисерима периодичних издања који је успешно реализован 2018. године остварио обим дигитализације по највишим светским стандардима у машински читљивој форми, распектабилан у европским размерама, а где се пројектне активности настављају и у 2019. години још амбициознијим пројектом који је подржало Министарство културе и информисања Владе Републике Србије. С друге стране, у 2018. години успешно је реализован пројекат Библиотечко-информациона делатност у функцији повећања видљивости, доступности и утицаја књижевнокритичке мисли у Србији: портал Српска књижевна критика који је донео успешну конкретизацију парадигме дуготрајног чувања и презентације тематски одабраних материјала кроз функционалност тематског репозиторијума. Још амбициознија пројектна активност у овом смислу наставља се 2019. године уз подаршку Министарства културе и информисања Владе Републике Србије.

\section{Анализа резутлата пројектног пословања у Универзитетској библиотеци у Београду}

Када се анализирају резултати пројектног пословања у Универзитетској библиотеци у Београду у претходно описаном периоду, уочавамо да су најважнији резутлати остварени успешном реализацијом пројеката довели до позитивног унапређења радних процеса и резултата рада у областима библиотечког пословања везаним за дигиталне технологије. Општи тренд раста важности дигиталних технологија у библиотекама може се уочити већ више од деценије и највећи део унапређења библиотечких услуга и увођења нових сервиса који се догодио у том периоду везан је управо за ове технологије. ${ }^{9}$ У том смислу Универзитетска библиотека је пројектним активностима на најбољи начин смањила опортунитетне трошкове, који могу бити изузетно велики уколико стратешки правац

9 Lyman Ross and Pongracz Sennyey, "The library is dead, long live the library! The practice of academic librarianship and the digital revolution", The Journal of Academic Librarianship 34, 2 (2008): 145-152. 
развоја установе почне дивергирати у односу на опште трендове развоја делатности, у овом случају библитечко-информационе. Увођењем система за аутоматизацију пословања који омогућава ефикасну имплементацију онлајн претраге каталога и имплементацијом дигиталног лисног каталога Универзитетска библиотека у Београду постала је прва велика библиотека у Србији и региону за чији је цео фонд омогућена доступност метаподатака на интернету. Развојем целокупног пословног процеса за дигитализацију - до машински читљивог облика фајлова, периодичних и осталих штампаних и руком писаних артефаката културног наслеђа, библиотека је омогућила увођење читавог низа нових услуга базираних на претраживости и расположивости свих елемената који чине садржај једног артефакта културног наслеђа, и још важније - претрагу и ефективан избор из великих колекција чиме је омогућено, на пример, креирање тематских колекција везаних за градове, историјске личности, догађаје или друге концепте за које је сада, на основу машинске читљивости материјала, лако објединити веће количине библиотечког материјала, а за шта је у претходном периоду било потребно уложити значајне временске и људске ресурсе. На овај начин омогућена је промена парадигме истраживачког рада у библиотекама и архивима, где је фокус сада могуће пребацити с временског улагања у проналажење материјала на повезивање материјала који је сада лако пронаћи, одабир и примену напредних техника обраде пронађених материјала који омогућавају нове увиде. У наредном периоду потребно је на пројектима засноване радне процесе у довољној мери ресурсно засновати како би се постигао довољан обим дигитализованог материјала у формату машинске читљивости. У сегменту организовања, чувања и презентабилности библиотечких материјала у окружењу репозиторијума постигнути су такође значајни помаци захваљујући успешно реализованим пројектима. Посебно су драгоцени разутати који се односе на презентовање посебних библиотека и рукописне заоставштине историјски важних личности кроз приватну кореспонденцију и комбиновање штампаних идигиталних извора везаних за ову тему.

Веома важни резултати остварени су пројектним активностима у домену обуке и усавршавања запослених. Нови радни процеси били би немогући без нових знања и вештина запослених за рад у прогрмаском окружењу обезбеђеном кроз пројектне активности. Такође, не треба занемарити ни улогу коју запослени играју као тренери и предавачи приликом преноса новоусвојених знања другим запосленима, волонтерима и запосленима у партнерским институцијама. Светска искуства, посебно у сектору академских библиотека, указују на велику важност менторског приступа и дуго- 
рочнијег праћења обуке запослених. ${ }^{10}$ Управо овакав приступ омогућен је у Универзитетској библиотеци у Београду захваљујући континуираним пројектним активностима, у оквиру којих се из године у годину наставља обука запослених по стратешки осмишљеним и развијаним векторима развоја библиотечко-информационе делатности и праксе, а везано за опредељење дигитализације штампаног и руком писаног културног наслеђа до машински читљивих формата, изградње репозиторијумске инфраструктуре и презентације одабраних сегмената библиотечких колекција за посебне корисничке групе. На овај начин постепено се гради организациона култура у којој се цени учење и стицање нових знања, вреднује предани рад и иновативност, а покушај да се створи нова вредност на најефикаснији начин се вреднује невезано од успешности крајње реалиазције.

Неопходно је истаћи и улогу успешне реализације пројеката у специфичној области изградње инфраструктуре која носи и пројектне и касније редовне радне процесе и форматирања ове инфраструктуре како би се у перспективи остварио потребан обим пословне операције који оправдава придев национални, који често иде уз пројекте националног финансирања. Захваљујући оваквом приступу у реализацији пројектних активности које граде дигиталну инфраструктуру, као и јединственом менаџмент приступу пројектним и редовним радним процесима, омогућено је да се крајем 2018. године створе услови за усвајање важног стратешког документа који су иницирале наше највеће библиотеке, а прихватило Министарство културе и информисања Владе Републике Србије - Националног оквира за дигитализацију периодичних издања у Републици Србији, препоруке за дигитализацију периодичних и осталих штампаних издања у највишем светском стандарду до форме METS-ALTO фајлова који су машински читљиви. Дигитална инфраструктура, изграђена кроз више конзеекутивно успешно реализованих пројеката националног и ЕУ финансирања, делимично заснована на готовим корпоративним производима, а већим делом на софтверским решењима која су производ домаће памети и прилагођавања софтвера у отвореном приступу за специфичне потребе библиотечке делатности и установа културе у Србији ${ }^{11}$, данас омогућава да Србија

10 Siobhan Stevenson and Julie Hannaford, "Workplace-integrated-learning: Preparing tomorrow's academic library workforce", The Journal of Academic Librarianship 45, 3 (2019): 234-241.

11 Smolenski, Nikola, Milena Kostic i Adam Sofronijevic, "Intrapreneurship and Enterprise 2.0 as Grounds for Developing In-House Digital Tools for Handling METS/ALTO Files at the University Library Belgrade", in Developing In-House Digital Tools in Library Spaces (Hershey, PA, USA: Igi Global, 2018), 92-116. 
као прва земља у региону и ширем окружењу има претраживу дигиталну библиотеку коју заједнички граде највеће установе културе у држави као централну тачку приступа претраживим и машински чиљивим подацима насталим дигитализацијом руком писаног и штампаног културног наслеђа. Ово достигнуће, можемо слободно рећи, у потпуности је остварено захваљујући успешној реалиазцији пројеката у Универзитетској библиотеци у Београду и пратнерским установама и захваљујући успешној примени пројектног менаџмента и мултипројектног присутпа управљању пројектима у дужем временском интервалу. Као такво може послужити као одлична препорука и пример најбоље националне праксе и у Србији и у региону за даље спровођење пројектних активности којима се граде нове дигиталне инфраструктуре или остварују други значајни циљеви на националном или регионалном нивоу.

\section{Закључак}

Пројектно пословање у Универзитетској библиотеци у периоду после 2000. године постајало је све више повезано с редовним радним процесима у смислу усклађивања пројектних задатака с остваривањем стратешких, дугорочних циљева који су омогућили унапређење редовних радних процеса и остваривање нових услуга за широке корисничке групе. Мултипројектно управљање постало је део редовног менаџмент процеса кроз године конзекутивног успешног реализовања више пројектних циљева истовремено кроз имплементацију више пројеката националног и међународног финансирања. Овакав приступ донео је нове инфраструктуре у дигиталној сфери, нову организациону културу која погодује доживотном учењу и сталном образовању запослених, као и нове односе са бројним партнерским установама у Републици Србији, региону и у свету. Кроз пројектно пословање Универзитетска библиотека у Београду значајно је осавременила и унапредила своје укупно пословање, омогућила увођење нових услуга, не само за својекориснике, већ и за кориснике библиотечких услуга многих библиотека у Србији и региону и поставила добре основе за даље унапређење пословања и наставак континуираног спровођења успешне реализације пројеката на националном нивоу и у партнерству с најважнијим институцијама културе у региону и Европи. 


\section{Literatura:}

1. Brzulović-Stanisavljević, Tatjana. „Zaostavština Joce Vujića”. U Biblionet: zbornik radova sa konferencije Dani matičnih biblioteka Srbije, 165-176. Beograd: Zajednica matičnih biblioteka Srbije, 2016.

2. Kerzner, Harold. "Project management best practices: Achieving global excellence". New York: John Wiley \& Sons, 2018.

3. Jerkov, Aleksandar i Adam Sofronijevic. "University of Belgrade library, Transkribus user experience". Paper presented at Transkribus User Conference 2017, 2-3 November, Technical University of Vienna, Vienna, available at: https://read. transkribus.eu/wp-content/uploads/2017/07/Jerkov_Uni_Belgrade_library.pdf(accessed 13 December 2018).

4. Meredith, Jack, Samuel Mantel and Scott Shafer. Project management: a managerial approach. New York: John Wiley \& Sons, 2017.

5. Munns, Andrew and Bassam Bjeirmi. "The role of project management in achieving project success”. International journal of project management 14, 2 (1996): 81-87.

6. Petrović, Dejan, Vesna Milićević i Adam Sofronijević. "Application of Project Management in Creative Industry". European Project Management Journal 7, 2 (2017): 59-66.

7. Ross, Lyman and Pongracz Sennyey. "The library is dead, long live the library! The practice of academic librarianship and the digital revolution". The Journal of Academic Librarianship 34, 2 (2008): 145-152.

8. Smolenski, Nikola, Milena Kostic i Adam Sofronijevic. "Intrapreneurship and Enterprise 2.0 as Grounds for Developing In-House Digital Tools for Handling METS/ ALTO Files at the University Library Belgrade”. In Developing In-House Digital Tools in Library Spaces, 92-116. Hershey, PA, USA: Igi Global, 2018.

9. Stevenson, Siobhan and Julie Hannaford. "Workplace-integrated-learning: preparing tomorrow's academic library workforce". The Journal of Academic Librarianship 45, 3 (2019): 234-241.

10. Tonchia, Stefano. "Project Cost Management and Finance". In Industrial Project Management, 153-170. Berlin: Springer, 2018.

11. Winston, Mark and Tara Hoffman. "Project management in libraries". Journal of Library Administration 42, 1 (2005): 51-61. 


\title{
Adam M. Sofronijević
}

University Library "Svetozar Marković”, Belgrade

sofronijevic@unilib.rs

\section{PROJECTS AT THE BELGRADE UNIVERSITY LIBRARY}

\begin{abstract}
The Belgrade University Library has successfully realized many projects with international and national funding since 2000. Many of these projects have laid foundations for the current working processes that define some of the dominant vectors of development of the library and information sector in Serbia and the region. This paper presents some of the most important results of project activities at the Belgrade University Library in the previous period and describes the most important and most successfully implemented projects with national and international funding. The results and management of these projects have been discussed and the possibilities for further development of the library and information sector in Serbia through the successful implementation of project activities and the combination of project and regular work activities as a strategic orientation of library management.
\end{abstract}

Keywords: projects, project management, international projects, national projects, University Library "Svetozar Marković”, Serbia.

Примљено: 25. септембра 2019.

Прихваћено: 28. октобра 2019. 